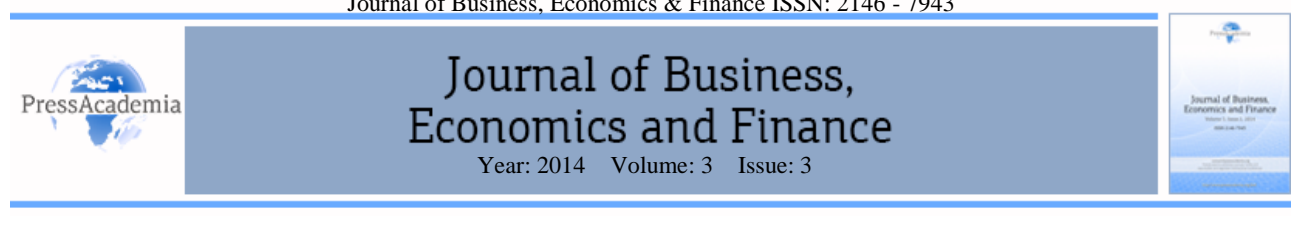

\title{
EDUCATED PROFESSIONALS ON BOARDS AT BORSA ISTANBUL
}

\section{Emrah ARIOGLU ${ }^{1}$}

${ }^{1}$ Cukurova University. E-mail: earioglu@cu.edu.tr

Keywords:

Professional Expertise;

Education;

Corporate Governance;

Borsa Istanbul

\begin{abstract}
This study aims to investigate the educational backgrounds and professional expertise of the directors in firms quoted at Borsa Istanbul. The findings of the study reveal that, a higher percentage of directors with advanced degrees such as PhDs, serve on various board committees, and a higher percentage of them are assigned as independent directors to the boards, compared to directors of lower educational qualifications. In addition, the findings suggest that a higher percentage of directors, who are professional experts such as accounting experts, lawyers or professors, serve on various committees of the boards, and a higher percentage of them are assigned as independent directors to boards. In contrast, a lower percentage of professional experts with advanced educational degrees serve as CEOs or chairmen of boards. These results suggest that technical skills and knowledge of directors are valued highly by companies, whereas they are not as highly valued in top managerial positions.
\end{abstract}

\section{INTRODUCTION}

The aim of this study is to investigate various aspects of non-observable diversity such as educational background or professional expertise of directors of boards (Erhardt et al., 2003) of firms quoted at Borsa Istanbul, with an emphasis on the characteristics of directors, as well as their independence, busyness, share ownership and committee appointments. Educational backgrounds and expertise of directors would be expected to signal their professionalism, which is an important topic in emerging economies, where the majority of public firms are controlled by families or business groups (Ararat et al., 2010). These families and groups are often governed by family members that could potentially lack a professional management perspective. Thus, decisions in the boardroom would be made in the interest of families or groups. This situation could adversely affect the confidence of investors in companies and financial markets. Consequently, economic development of financial markets, which is vital for emerging economies, could be impaired. Therefore, an investigation of the level of professionalism emerges as an important topic for financial markets in emerging economies, such as the Turkish economy. 
There is extensive research in management and corporate governance literature investigating the potential effects of the existence of directors with different educational backgrounds and professional expertise, on issues such as diversity and firm value. For instance, studies such as Carpenter and Westphal (2001), Westphal and Bednar (2005), Ruigrok et al. (2006), Jalbert et al. (2010), Anderson et al. (2011) and Dalziel et al. (2011) investigate topics related to the educational background of directors and top executives. On the other hand, Rosenstein and Wyatt (1990), Agrawal and Chadha (2005), DeFond et al. (2005), Jiang and Murphy (2007), Guner et al. (2008), Ferreira (2010), Anderson et al. (2011), Sisli-Ciamarra (2012), Francis et al. (2014), and Litov et al. (2014) investigate topics related to the professional expertise of directors. However, the summary of discussions in these and other related studies regarding potential benefits and costs of existence of directors with different educational and occupational backgrounds are left to the following sections. One point that is noteworthy is the reason underlying the choice for the sample years covered in the study. The Principles of Corporate Governance (PCG) of Turkey, which introduced various mandatory requirements for public firms in terms of their corporate governance applications, improved the disclosure of public information by firms. Thus, following the effectiveness of PCG, it is possible to acquire detailed information about the directors of firms through the annual reports and official web pages of these firms.

In section 3, educational backgrounds of directors are investigated. The findings show that a lower percentage of directors with PhD degrees are females and are the chairmen of boards of directors, compared to directors with no PhDs. In addition, a higher percentage of these directors have degrees earned from institutions not located in Turkey. Also, a higher percentage of them are financial experts, lawyers, or professors. The findings also show that a higher percentage of these directors serve on audit, governance and risk committees of firms, and a higher percentage of them are independent directors. These results support arguments that advanced degrees could provide the directors with unique skills, which could lead them to be effective monitors. In terms of share ownership, these directors own fewer shares in firms. The findings in section 3 also show that substantially high percentage of directors with only a high school degree or lower are chairmen, compared to directors with higher degrees of education. In addition, a lower percentage of them are financial experts, accounting experts, lawyers or professors. Also, a lower percentage of them serve on audit, governance or risk committees, and a lower percentage of them are independent directors.

Lastly, the findings in section 3 show that a higher percentage of directors with degrees earned from institutions located outside of Turkey have PhDs and masters degrees, compared to directors with no degrees earned from foreign institutions. In addition, a higher percentage of these directors are financial experts. However, a lower percentage of them are accounting experts. Also, a lower percentage of directors with foreign education sit on audit and governance committees. Lastly, a lower percentage of them are independent directors. Based on these figures, it could be argued that companies do not value foreign education higher, compared to education in Turkey, and do not consider directors with degrees earned from foreign institutions as potentially better monitors. 
In section 4, the professional expertise of directors is investigated. The findings show that a lower percentage of financial experts are CEOs, compared to directors that are not financial experts. In addition, a lower percentage of professional experts are chairmen of companies. In terms of the education degrees earned, a higher percentage of financial experts and professors, and a lower percentage of accounting experts have degrees earned from institutions located outside of Turkey, compared to other directors. Also, a higher percentage of financial experts, lawyers and professors have PhD degrees.

The findings in section 4 also show that a higher percentage of directors that are accounting experts, lawyers or professors sit on all three committees of the boards, compared to other directors. This evidence could be considered to suggest that companies potentially value professional expertise in committee appointments and a higher percentage of professional experts are assigned to committees. Similar patterns are observed for director independence. Also, a higher percentage of directors that are accounting experts, lawyers, or professors are assigned to boards as independent directors, who are expected to be more effective monitors compared to other directors. However, a similar situation is not observed for financial experts. Overall, the evidence could be considered to suggest that companies value professional experts, who have technical knowledge and skills, when they assign independent directors to their board. In terms of director busyness, a higher percentage of financial experts, accounting experts and professor are busy directors compared to other directors. On the other hand, professional experts have lower percentage of share ownership in firms.

The findings in section 4 also reveal that a lower percentage of directors with professional expertise are CEOs or chairmen of companies, compared to directors who do not have the professional expertise. In addition, a higher percentage of them have degrees earned from institutions located outside of Turkey, and a higher percentage of them have advanced educational degrees such as PhDs. Also, a higher percentage of professional experts are assigned to committees of the boards, and a higher percentage of them are independent directors. Overall, the findings in the study highlight the importance of advanced educational degrees and the expertise of directors on boards of public companies.

\section{DATA}

In this study, hand-collected data gathered from the annual reports of firms and the official web pages of companies, is employed. Banks in Turkey are subject to different corporate governance related regulations, compared to other firms. Thus, banks that are quoted at Borsa Istanbul are excluded from the sample. This leaves a sample of 2079 board members for the end of year 2012, and 2066 board members for the end of year 2013. In addition, data for some of the variables employed in this study were not available for all the directors on the board of directors. 
Table 1: Descriptive Statistics for Directors

\begin{tabular}{lrr}
\hline & Director Characteristics & \\
\hline & $\mathbf{2 0 1 2}$ & $\mathbf{2 0 1 3}$ \\
\hline Number of Directors & 2079 & 2066 \\
PhD Degree & 181 & 186 \\
Masters Degree & 567 & 543 \\
College Degree & 1006 & 1016 \\
High School Degree or Lower & 91 & 86 \\
Foreign education & 778 & 753 \\
No Foreign education & 1062 & 1072 \\
Financial Expert & 745 & 769 \\
Not a Financial Expert & 1153 & 1105 \\
Accounting Expert & 210 & 213 \\
Not an Accounting Expert & 1675 & 1653 \\
Lawyer & 126 & 111 \\
Not a Lawyer & 1844 & 1825 \\
Professor & 119 & 119 \\
Not a Professor & 1850 & 1816 \\
Audit Committee Member & 551 & 559 \\
Governance Committee Member & 628 & 664 \\
Risk Committee Member & 236 & 487 \\
Average Membership Number & 3.32 & 3.45 \\
Independent Member & 607 & 613 \\
Busy Director & 171 & 195 \\
\hline
\end{tabular}

In terms of the variables throughout the paper, share ownership states the percentage of shares owned by a director alone. The highest level of degree earned by a director is defined by the education level. Foreign education states whether a director has a degree earned from an institution not located in Turkey. A financial expert is a director who has been or currently is the CEO, or was/is on the board of a financial institution. A director is defined as an accounting expert if she is certified as a CPA or equivalent. Professor defines whether the director officially has or had a professor title, either on a tenure track or clinical position. Lawyer defines that a director is or was performing as an attorney in law. Membership number states the total number of firms that are not non-profit, on whose boards the director sits. A director is defined as an independent director if she meets the independence requirements defined in PCG. A busy director is an individual who is an independent director on the focal firm and is on the board of at least three different firms that are not non-profits (Fich and Shivdasani, 2006). The descriptive statistics regarding the sample are presented in Table 1. The Table shows that 186 of the directors have PhD degrees, whereas 543 have masters and 1016 have college degrees as the highest level of educational degree earned, at the end of 2013. 86 of the directors have high school degrees or lower education. The figures are similar for the end of 2012. In addition, among the directors in the samples, 769 are financial experts at the end of 2013. 213 are accounting experts, 111 are lawyers and 119 are professors. 
These directors hold, on average, 3.45 and 3.32 board seats in for-profit firms, at the end of 2013 and 2012, consecutively. In addition, around $30 \%$ of the directors are independent directors according to the PCG standards. At the end of 2013, approximately $9.43 \%$ of the directors in the sample are busy directors. The average age of the directors in the sample, at the end of both years, is around 54 .

\section{EDUCATION}

Directors from various educational backgrounds could potentially provide positive effects of diversity in the boardroom such as enhanced creativity, different perspectives on important corporate issues, and distinct and unique sets of skills and leadership (Burgess and Tharenous, 2002; Carter et al., 2003; Arfken et al., 2004; Peterson and Philpot, 2007; Anderson et al., 2011; Dobbin and Jung, 2011). They could also provide the negative effects such as board members treating other boards members as out-group individuals, or the existence of potential conflicts and communication problems (Shin, 2012; Arioglu, 2014).

Other than these effects, the educational backgrounds of directors could be an important resource for firms in terms of potential external connections, which directors establish during their education or through their educational associations. However, as argued by Westphal and Bednar (2005), these affiliations could also potentially serve during the director appointment process as a result of in-group biases, which could potentially tend to increase pluralistic ignorance that in return might lead to poor firm performance.

In addition, levels of education and expertise gained by directors could affect their quality of advising and monitoring and scope of the input they bring to boardrooms (Ruigrok et al., 2006), as well as their actions in boardrooms. This, in return, could affect firm performance. In support of this argument, Anderson et al. (2011) show that even though managers prefer homogenous boards, shareholders value diversity in terms of educational background and there is a positive relationship between board heterogeneity and firm performance. Jalbert et al. (2010) provide evidence highlighting the importance of education of top executives in their career paths to the top. However, Gottesman and Morey (2006), and Bhagat et al. (2010) show that firms, whose CEOs have more prestigious educational backgrounds, do not outperform other firms.

What would be important is not only homogeneity of education in the boardroom, but also the highest levels of degrees earned by board members. Audretsch and Lehmann (2006) argue that an academic degree such as PhD could signal to superior quality of human capital of board members. A PhD could indicate that a director had spent a substantial amount of time in the academic environment, which had provided the director with valuable knowledge necessary for strategic decision making (Carpenter and Westphal, 2001). In accordance with this view, Dalziel et al. (2011) argue that advanced degrees such as PhDs could equip directors with extra skills that could be beneficial for the firm, especially in their $R \& D$ efforts.

Lastly, whether or not directors earned their degrees in institutions located in countries other than the home country, could be an important factor in the quality of decisions that they make. 
When directors earn degrees in countries with cultural dynamics different from those of the home country, they could earn different cultural perspectives, which could potentially have positive effects on the way they think and solve problems. It should also be kept in mind that the education levels of directors would be important determinants of the occupational differences and expertise of the board members.

Results regarding the education levels of directors are presented in Appendix 1. In Appendix 1 , comparisons in terms of significance are conducted in a manner that values of variables for the directors in the $\mathrm{PhD}$, masters and college categories, as the highest level of degree earned, are compared with values of those variables for directors, who have a lower level of education. For example, the values of variables for directors with master degrees are compared with values of the same variables for directors, who have only college degrees or lower degrees. For the category of directors with high school degree or lower levels of education, values are compared with the values for directors, who have either PhDs, masters or college degrees.

What is observed in Appendix 1 is that at the end of 2013, 186 directors had PhD degrees, whereas 543 directors had master degrees as the highest degree earned. 1016 of directors in the sample, at the end of 2013, had college degrees as the highest level of degree earned, and 86 of them had high school degree or a lower degree. Appendix 1 also shows that a significantly lower percentage of directors with PhD degrees, $3.23 \%$, are females, compared to other directors. This could be an outcome of the fact that, women did have the opportunity to follow academic careers as often as men did in the past. The Table also shows that a significantly lower percentage of directors with PhD degrees, $5.98 \%$, are the chairmen of boards of directors, compared to other directors. This could be an outcome of the fact that a higher percentage of directors with PhDs are appointed to the boards as independent directors, who are expected to be more effective monitors, which is also a trait expected from directors with high levels of education (Ruigrok et al., 2006). Thus, their effectiveness in monitoring the chairmen of boards might be highly valued.

Compared to the group of directors with no PhD degrees, a higher percentage of directors with PhDs have degrees earned from institutions not located in Turkey, $60.75 \%$. In addition, a higher percentage of them are financial experts, $55.91 \%$, and a higher percentage of them are lawyers, $11.83 \%$. Also, a higher percentage of them are professors, $50.00 \%$. However, a lower percentage of them are accounting experts, $6.99 \%$. The observation that significantly higher percentage of them is financial experts could be considered in support of the argument that advanced degrees help directors become better qualified. On the other hand, the fact that half of directors with PhDs are professors could also be considered in the same manner. However, it should be noted that a PhD is traditionally required to become a tenure track professor, and thus, this observation should not be surprising.

Appendix 1 also presents the percentage of directors with PhDs that serve on various board committees. $50.27 \%$ of directors with PhDs serve on audit committees, whereas $47.03 \%$ of them serve on governance committees, and $37.30 \%$ of them serve on risk committees. All three of these boards exist in companies in order to provide oversight over boards and these results suggest that directors with advanced degrees are considered to have unique skills that would help them be more effective monitors. 
In addition, Appendix 1 shows that directors with PhDs serve on fewer boards, 2.68 boards on average, compared to other directors. They are also, on average, older than other directors.

This could be an outcome of directors spending longer periods of time on their educational careers and joining workforce at older ages. In addition, half of these directors are professors and in academia, it takes long time for professors to set their reputations and thus, they could be appointed to boards at older ages. As mentioned earlier, a significantly higher percentage of directors, $53.22 \%$, are independent directors. This could be an outcome of the view that these directors with advanced degrees are highly qualified, and therefore, could serve as more effective monitors, compared to other directors. In terms of share ownership in firms, these directors own significantly fewer shares in firms, $0.46 \%$, compared to other directors. Since the PCG requires a director not to own more than 1.00 $\%$ of shares of companies, in order to be considered as independent, and almost half of the directors with PhDs are independent directors, this could be considered as a natural outcome.

In addition, Appendix 1 presents findings regarding directors with masters degrees as the highest level of educational degree earned. 543 of the directors, at the end of 2013, in the sample have master degrees. In terms of the ratio of these directors that are female, foreigner, or CEOs and chairmen in the focal firms, they do not differ significantly from directors with lower levels of education. However, a significantly higher percentage of them have degrees earned from foreign institutions, around $70 \%$. This could be an outcome of directors joining highly reputable executive MBA programs in other countries, especially in the US, at some point during their careers. In addition, a higher percentage of them are financial experts, $44.92 \%$. This figure, in addition to the observation regarding directors with PhDs, could be considered to suggest that directors with high levels of education are valued highly, and thus, are hired by financial institutions, where technical skills would be expected to be more vital. Also, a lower percentage of these directors are accounting experts, $8.12 \%$, and a higher percentage of them are professors, $2.58 \%$. Surprisingly, what is observed in Appendix 1 is that a higher percentage of directors with master degrees are not appointed to either audit committees, governance committees or risk committees of firms.

Appendix 1 also shows that directors with masters degrees, on average, sit on boards of more companies, 4.17 companies, compared to directors with lower levels of education. Also, a significantly higher percentage of these directors are not appointed to boards as independent directors. In terms of age, directors with master degrees are younger than directors with lower degrees. On average, they are 53.21 years old. Lastly, these directors own, on average, $1.41 \%$ of the shares of the company, which is significantly less compared to the share ownership of directors with lower degrees of education. Average share ownership by directors with high school degree or lower is $8.75 \%$ and this could help explain the observation just mentioned. It could be possible that directors with degrees lower than master degree, especially those with high school degree or lower, are older directors, who are potentially the entrepreneurs who founded the companies, rather than pursuing professional careers. 
Thus, their share ownership in companies is significantly higher, compared to directors with more advanced degrees. The last two columns of Panel B of Appendix 1 support this argument.

Appendix 1 also presents findings regarding directors with only college degrees. 1016 of the directors in the sample, at the end of 2013, have only bachelor degrees earned from colleges.

In terms of their professional expertise and appointments in various board committees, the figures suggest that compared to directors with no college degrees, a higher percentage of these directors are professional experts. In addition, a higher percentage of them serve on board committees. Also, a higher percentage of them are independent directors, who are also busy directors. These figures could be considered as evidence suggesting that companies value some form of higher education in their board of director appointments. Also a significantly lower percentage of them are chairmen in companies. Potential causes of this situation are discussed in the following paragraphs. To summarize, $12.52 \%$ of directors with only college degrees are chairmen in firms, $11.22 \%$ of them are foreigners, $25.32 \%$ of them have degrees earned at institutions located outside of Turkey, and 37.52 $\%$ of them are financial experts. In addition, $14.97 \%$ of them are accounting experts, whereas $5.74 \%$ of them are lawyers, and $28.15 \%$ of them serve on audit committees. Also, $33.30 \%$ of them serve on governance committees, and $25.33 \%$ serve on risk committees. $30.51 \%$ of them are independent directors and $10.64 \%$ of them are busy. Lastly, the average shares owned by them in companies are $2.13 \%$.

Lastly, Appendix 1 also presents findings regarding directors with a high school degree or a lower degree. Compared to directors with higher degrees of education, surprisingly, a substantial percentage of directors with only a high school degree or lower education are chairmen of the boards, $30.95 \%$. Once again, this could potentially be an outcome of them being founders of companies, and elder members of controlling families, who could be considered as lacking technical skills earned through higher education, but still possess valuable entrepreneurial skills and on-the-job experiences and skills. In addition, $25.58 \%$ of them are financial experts, whereas $2.33 \%$ are accounting experts and none of them are professors or lawyers. These figures are significantly lower, compared to directors with higher levels of education.

Appendix 1 also shows that $14.46 \%$ of these directors serve on audit committees. $19.28 \%$ serve on governance, and $14.47 \%$ serve on risk committees. All of these figures are significantly lower, when compared to the figures for remaining directors. These observations could be considered to suggest that companies value higher levels of education of directors when appointing them to various committees of the boards. Also, in support of effective monitoring arguments, a significantly lower percentage of directors with high school degree or lower are independent directors, $13.95 \%$. As discussed earlier, their average share ownership is $8.75 \%$. Lastly, none of these directors are busy directors, even though on average, they sit on the boards of 3.45 for-profit companies. Thus, the busyness figure is an outcome of the requirement in the busyness definition, where the director is required to be independent in order to be considered busy. The figures for the end of 2012 are very parallel to the results discussed so far. 
Next, I present findings regarding directors with degrees earned in foreign institutions and domestic institutions, in Table 2. What is observed in Table 2 is that at the end of 2012, 778 directors had foreign education, whereas 753 of directors on public firms' boards had degrees earned from institutions located outside of Turkey at the end of 2013. The Table also shows that in terms of chairmen or CEO positions, directors with foreign education do not differ significantly from other directors, at the end of both years. Not surprisingly, a significantly higher percentage of them, $25.9 \%$ are foreigners, at the end of 2013.

Among directors who have foreign educational backgrounds, a significantly higher percentage of them have PhD and masters degrees, $15.01 \%$ and $50.73 \%$, consecutively. On the other hand, $34.00 \%$ of them have college degrees. These figures should not be surprising as it could be argued that individuals that earn degrees abroad would prefer to do so at further stages of their educational careers.

Table 2: Foreign Education of Directors

\begin{tabular}{lrr|rr}
\hline & \multicolumn{2}{c}{$\mathbf{2 0 1 2}$} & \multicolumn{2}{c}{$\mathbf{2 0 1 3}$} \\
\hline & $\begin{array}{r}\text { Foreign } \\
\text { Education }\end{array}$ & $\begin{array}{r}\text { No Foreign } \\
\text { Education }\end{array}$ & $\begin{array}{r}\text { Foreign } \\
\text { Education }\end{array}$ & $\begin{array}{r}\text { No Foreign } \\
\text { Education }\end{array}$ \\
\cline { 2 - 4 } Number of Directors & 778 & 1062 & 753 & 1072 \\
Female & $11.05 \%$ & $11.21 \%$ & $10.62 \%$ & $10.63 \%$ \\
CEO of the Firm & $6.30 \%$ & $8.29 \%$ & $6.77 \%$ & $7.84 \%$ \\
Chairman & $13.92 \%$ & $15.26 \%$ & $13.72 \%$ & $14.73 \%$ \\
Foreigner & $* * * 25.19 \%$ & $0.28 \%$ & $* * * 25.9 \%$ & $0.28 \%$ \\
PhD Degree & $* * * 14.78 \%$ & $6.21 \%$ & $* * * 15.01 \%$ & $6.81 \%$ \\
Masters Degree & $* * * 51.80 \%$ & $15.35 \%$ & $* * * 50.73 \%$ & $14.93 \%$ \\
College Degree & $* * * 33.16 \%$ & $69.96 \%$ & $* * * 34.00 \%$ & $70.43 \%$ \\
High School or Lower & $* * * 0.26 \%$ & $8.48 \%$ & $* * * 0.26 \%$ & $7.83 \%$ \\
Financial expert & $* * * 45.78 \%$ & $34.54 \%$ & $* * * 46.65 \%$ & $37.14 \%$ \\
Accounting Expert & $* * * 5.97 \%$ & $15.26 \%$ & $* * * 7.10 \%$ & $14.58 \%$ \\
Lawyer & $5.66 \%$ & $7.00 \%$ & $5.44 \%$ & $6.06 \%$ \\
Professor & $* * * 8.61 \%$ & $4.54 \%$ & $* * * 8.37 \%$ & $4.85 \%$ \\
Audit Committee Member & $* * * 24.47 \%$ & $30.75 \%$ & $* * * 23.19 \%$ & $31.74 \%$ \\
Governance Committee & & & & \\
Member & $* * * 27.37 \%$ & $35.05 \%$ & $* * * 28.15 \%$ & $36.52 \%$ \\
Risk Committee Member & $12.68 \%$ & $12.61 \%$ & $25.07 \%$ & $25.24 \%$ \\
Average Membership & & & & \\
Number & $* * 3.66$ & 3.21 & $* * 3.84$ & 3.31 \\
Age & $* 53.61$ & 54.87 & 54.35 & 54.97 \\
Independent Member & $* * * 26.09 \%$ & $32.38 \%$ & $* * * 25.23 \%$ & $33.76 \%$ \\
Busy Director & $11.26 \%$ & $9.14 \%$ & $12.34 \%$ & $9.92 \%$ \\
Share Ownership \% & $* * * 1.15 \%$ & $2.65 \%$ & $* * * 1.24 \%$ & $2.64 \%$ \\
\hline
\end{tabular}

$* * *, * *$, and $*$ present significance at $1 \%, 5 \%$, and $10 \%$ levels.

Table 2 also shows that a higher percentage of these directors are financial experts, 46.65 $\%$, compared to directors with no foreign education, whereas a significantly lower percentage of them are accounting experts, $7.10 \%$. 
Surprisingly, the Table also shows that a significantly lower percentage of directors with foreign education serve on audit and governance committees. The figures are $23.19 \%$ and $28.15 \%$, consecutively. A similar situation is observed in terms of the percentage of directors that are independent. $25.23 \%$ of directors that have foreign educational backgrounds are independent directors. This figure is significantly lower, compared to other directors. Thus, based on these figures, one could argue that companies do not value foreign education more highly and do not consider directors with degrees earned from foreign institutions as potentially better monitors. Similar patterns are observed for the end of 2012.

Overall, the findings presented so far highlight the importance of advanced educational degrees, such as PhDs, as well having at least a college degree, in terms of having professional expertise, committee memberships and director independence. However, the same cannot be stated for degrees earned from institutions located outside of Turkey.

\section{PROFESSIONAL EXPERTISE}

Potential benefits and costs of board heterogeneity discussed in the previous section could also apply to diversity in terms of professional expertise. However, there could be some other potential costs and benefits that are unique to the professional expertise of directors. In this section, I first discuss the importance of board members with financial/accounting expertise. After the financials scandals of the last decade, the Sarbanes-Oxley Bill was adopted in the US. Following the Bill, companies in US markets are required to have at least one financial expert in their audit committees. However, in Turkish capital markets, such requirements do not exist.

One could argue that committee members without the financial expertise would be less likely to detect accounting-related problems, such as financial reporting problems (Agrawal and Chadha, 2005). Also, better understanding of accounting principles and financial statements could have a positive effect on the oversight provided by the board (Guner et al., 2008). In addition, directors with financial and accounting expertise could be more sensitive to financial issues of the firm. They could also monitor the financial performance of the company more effectively, compared to non-expert directors (Anderson et al., 2011; Dalziel et al., 2011).

On the other hand, if a banker joins the board of a firm, this could signal to the market the confidence of the bank that the firm is not likely to experience financial distress (Kroszner and Strahan, 2001). In addition, directors with financial expertise could create opportunities for firms to have access to specific investors and could be more involved in supplying capital for companies (Dalziel et al., 2011). If an employee of a financial institution, which has a lending relationship with the firm, joins board of the firm, the financial expert might conduct more effective monitoring that would be beneficial for both the firm and the financial institution (Ferreira, 2010). This situation could alter the financial decisions and the financial outcomes for firms as well. Sisli-Ciamarra (2012) provide evidence suggesting that when an employee of a financial creditor is on the board of a company, this leads to increased debt in the firm's financial mix as a result of increased private debt, as well as decreased cost of debt. 
Thus, the characteristics of a financial expert and her external ties would be an important factor on the potential effects of her existence on the firm's board. However, when the financial expert is tied to a financial institution, it is possible that the lending financial institution could have enhanced bargaining power with the firm and could potentially deal for stricter collateral and covenant requirements, as a result of the informational advantage gained through the director (Sisli-Ciamarra, 2012).

If the firm is financially constrained, the financial experts on the board could be beneficial in creating access to more funds for the potential value-creating investments of the firm. However, it should be kept in mind that these extra funds would not necessarily be used in the best interest of shareholders.

They could be provided just in the interest of the financial institution, which would affect the wealth of shareholders negatively (Guner et al., 2008). Another potential downside is based on the argument of Agrawal and Chadha (2005). The researchers argue that existence of financial or accounting experts might lead audit committee members to pay less attention to specific issues. In this case, if the financial expert is not monitoring effectively, this could even lead the audit committee to be less effective in detecting accounting related problems.

In empirical studies, Rosenstein and Wyatt (1990) provide evidence suggesting that significant abnormal returns are observed, when outside directors with financial expertise are added to boards. DeFond et al.'s (2005) evidence is suggestive of positive reactions following the appointment of an accounting or financial expert to the audit committee of the boards. Krishnan and Gnanakumar (2008) show that accounting expertise of members of audit committees leads to enhanced monitoring and accounting conservatism. Chan and $\mathrm{Li}(2008)$ show that financial experts have a positive effect on firm value. Guner et al. (2008) find that financial experts in the boardroom affect corporate decisions. However, the effects are in the interest of their own institutions. In addition, firms that have investment bankers on the boards do worse in terms of acquisitions. Anderson et al. (2011) find that occupational heterogeneity has a positive influence on firm performance and that shareholders value this type of heterogeneity. On the other hand, Van Ness et al. (2010) provide evidence suggesting that as the number of financial and accounting experts on boards increase, firm performance is affected negatively.

Next, I discuss the importance of the existence of another type of professional expertise in boards: academicians. Based on the view that independent board members have positive influence on firm value (Hermalin and Weisbach, 1991; Arioglu and Kaya, 2014), academic directors could be likely to affect corporate governance and firm value positively, since they are mostly outside directors by nature (Francis et al., 2014). In addition, academic directors' knowledge of specific concepts in their fields of expertise could lead them to be better advisors for board decisions (Forbes and Milliken, 1999). Academicians could be expected to consider problems in a scientific approach and these different perspectives could be useful in the decision making and problem solving processes of the board. Also, they are trained to be critical thinkers with unique opinions and judgments (Jiang and Murphy, 2007). 
Additionally, these directors could have an important resource-dependence role and the external links of the board could increase, as the occupational diversity of the board increases (Hillman et al., 2002). In accordance with these potential benefits, Francis et al. (2014) show that $40 \%$ of S\&P 1500 firms have at least one academician on their boards. The existence of academicians, who are scientists in nature, could be expected to be valueenhancing especially in the case of firms that focus on technology and invest heavily in R\&D, since these scientists could bring external scientific knowledge to the firm (Audretsch and Lehmann, 2006). In addition, the existence of academicians on board could have other potential effects on issues such as compensation policy, CEO turnover, corporate innovation, acquisitions and earnings quality (Francis et al., 2014).

However, academicians might be more concerned about scholar research instead of important factors for success in business, which could lead them to devote majority of their time to scientific research (Jiang and Murphy, 2007; Francis et al., 2014).

They could also be expected to lack on-the-job experience, which is important in the improvement of skills required for high-quality management. Therefore, their existence in management could have adverse effects on firm value as well. Supportive of this argument, Francis et al. (2014) provide evidence suggesting that academicians with administrative positions in the firms are associated with lower firm performance. Also, Van Ness et al. (2010) provide evidence suggesting that as the number of academicians on boards increase, firm performance is affected negatively.

Lastly, I discuss the importance of the existence of lawyers in the boards of firms, on which there is very limited research in corporate governance literature. To begin with, intuitively, one could argue that directors with expertise in law and regulations could benefit the firm not only when the firm is subject to law suits, but also before the firms takes any actions that could be subject of potential lawsuits. These could include issues that would arise in relationships with customers, suppliers, or even the firm's own employees.

A director, who is a lawyer, could spot any potential issues that could cause legal concerns for the firm. In addition, she could provide the boardroom with a perspective that could not be provided in a setting without the existence of a lawyer. Also, she could help deal with legal and regulatory problems as they emerge. In the instance that firms have valuable assets such as patents, lawyer-directors could be beneficial in the protection of those assets (Litov et al., 2014). However, in terms of the potential costs related to the existence of lawyers on the boards of firms, Litov et al. (2014) argue that she might be less effective in monitoring the actions of the boards that she is a member of. This could be expected as a result of the possibility that lawyer-directors lack necessary firm-specific information about the complexity of the operations of the company.

Litov et al. (2014) provide evidence suggesting that firms with lawyers on the boards of directors are associated with significant increases in firm value. In addition, Litov et al. show that existence of lawyer-directors affects the CEO risk taking incentives and the existence of entrenchment provisions such as poison pills. In terms of characteristics of these lawyerdirectors on a large sample of public firms in the US, the researchers show that these directors are mostly independent male directors, with board appointments in two other public firms, on whose various committees they stand. 
Around one-fourth of these directors are on audit and governance committees, whereas one-third of them are on risk management committees. In another study, Gray and Nowland (2014) show that the shareholders of companies benefit from the existence of professionals such as lawyers, accountants, consultants and bankers, in the boardroom.

Findings of this study regarding the professional expertise of directors on boards are presented in Appendix 2 and Table 3. Appendix 2 shows that, at the end of 2013, 769 of the directors in the sample are categorized as financial experts. On the other hand, 213 of them are categorized as accounting experts, whereas 111 are lawyers and 119 are professors. A significantly lower percentage of these financial experts are CEOs of firms, whereas a lower, but insignificant, percentage of accounting experts, lawyers and professors are CEOs in firms. This evidence could be considered to suggest that firms do not value professional expertise highly when they assign CEOs.

In terms of chairmen of companies, what is observed is that a significantly lower percentage of professional experts are chairmen of companies. Financial experts are the exception this time, since, even though a lower percentage of them are chairmen, the difference is not statistically significant, compared to other directors. $12.52 \%$ of financial experts are chairmen in companies, whereas this figure is $4.23 \%, 3.67 \%$, and $2.52 \%$ for accounting experts, lawyers and professors, consecutively. This evidence suggests that companies do not consider directors with professional expertise as more effective leaders, when assigning them to the position of the chairmen of the board. This could be a potential outcome of a belief that professional expertise and related skills are not sufficient enough to manage the board. Alternatively, it could be an outcome of chairmen being members of families or controlling groups, and that these controlling parties do not delegate authority to professionals.

In terms of the education degrees earned by the directors in the sample, what is observed from Appendix 2 is mixed evidence. A significantly higher percentage of financial experts and professors have degrees earned from institutions located outside of Turkey, compared to other directors. The percentages of these directors with foreign education are $46.71 \%$ and $54.78 \%$, consecutively. The percentage of lawyers, $38.68 \%$, with foreign education, however, is not significantly different, compared to other directors. On the other hand, a significantly lower percentage of directors that are accounting experts, have degrees earned from institutions located outside of Turkey, $25.36 \%$.

In terms of educational degrees earned by the professional experts, Appendix 2 shows that, at the end of 2013, a significantly higher percentage of financial experts, lawyers and professors, $13.95 \%, 21.05 \%$ and $79.51 \%$, have PhD degrees. However, this figure is not significantly different for lawyers, compared to non-lawyers. In terms of master degrees, no category of professional experts in the sample has a significantly higher percentage of directors with master degrees. This evidence could be considered to suggest that, only advanced degrees such as PhDs could potentially have effects on the likelihood of directors having professional expertise. Still, this is just an observation and such a relationship could be investigated in future studies, in a causal manner.

Some surprising findings are observed in Appendix 2, in terms of committee appointments of directors with professional expertise. 
$29.45 \%$ of the directors, who are financial experts, serve on audit committees, whereas $34.95 \%$ serve on governance committees, and $27.23 \%$ serve on risk committees. Compared to other directors, a significantly higher percentage of financial experts are not assigned to any of the three committees of the boards. These figures are surprising, since one could expect a significantly higher percentage of these directors to sit on board committees, especially on audit committees, since these directors would be expected to have more advanced technical financial skills that would lead them to be more effective monitors. However, this expectation is fulfilled in the case of accounting experts. A significantly higher percentage of them sit on board committees. $45.89 \%$ of the directors, who are accounting experts, serve on audit committees, whereas $51.21 \%$ serve on governance committees, and $35.27 \%$ serve on risk committees. This evidence could be considered to suggest that companies value accounting expertise in committee appointments highly. Such an expertise would be vital, especially in the functioning of the audit committee, and companies appear to be aware of this.

Similar patterns are observed for lawyers and professors, in terms of their committee appointments, compared to other directors.

Overall, the evidence suggests that companies potentially value professional expertise in committee appointments and a higher percentage of professional experts are assigned to these committees, expect financial experts. One could potentially argue that the exception of financial expertise should not be surprising since the other three professions require some additional technical skills and knowledge, whereas the definition of financial expertise does not include such requirements. It is possible that director $X$ sits on the board of a financial company, not because she has superior financial skills, but because she is a family member. However, this would not qualify her as an accounting expert, a lawyer, or a professor.

What is observed from Appendix 2, in terms of independence, is that a significantly higher percentage of directors, who are accounting experts, lawyers, or professors, are assigned to boards as independent directors, who are expected to be more effective monitors, compared to other directors. $47.89 \%$ of accounting experts are independent directors, whereas $53.15 \%$ of lawyers and $70.59 \%$ of professors are independent directors. A similar situation, however, is not observed for financial experts. Once again, this evidence could be considered to suggest that companies value professional experts, who have technical knowledge and skills, when they assign independent directors to their boards, compared to other directors. 
Table 3: Professional Experts vs. Non-Experts

\begin{tabular}{lrr|rr}
\hline & \multicolumn{3}{c}{$\mathbf{2 0 1 2}$} & \multicolumn{2}{c}{$\mathbf{2 0 1 3}$} \\
\hline & $\begin{array}{r}\text { Professional } \\
\text { Experts }\end{array}$ & Non-Experts & $\begin{array}{r}\text { Professional } \\
\text { Experts }\end{array}$ & Non-Experts \\
\cline { 2 - 5 } Number of Directors & 953 & 951 & 966 & 915 \\
CEO of the Firm & $* * * 5.35 \%$ & $9.15 \%$ & $* * * 5.49 \%$ & $9.18 \%$ \\
Chairman & $* * * 10.96 \%$ & $17.90 \%$ & $* * * 10.81 \%$ & $17.50 \%$ \\
Foreign education & $* * 45.08 \%$ & $39.36 \%$ & $* * 43.68 \%$ & $38.32 \%$ \\
PhD Degree & $* * * 16.41 \%$ & $33.90 \%$ & $* * * 16.27 \%$ & $3.85 \%$ \\
Masters Degree & $29.32 \%$ & $32.56 \%$ & $29.65 \%$ & $29.93 \%$ \\
College Degree & $51.96 \%$ & $56.25 \%$ & $* 51.39 \%$ & $59.29 \%$ \\
High School or Lower & $* * * 2.29 \%$ & $7.78 \%$ & $* * 2.67 \%$ & $6.91 \%$ \\
Financial expert & $78.91 \%$ & & $80.35 \%$ & \\
Accounting Expert & $22.60 \%$ & & $22.49 \%$ & \\
Lawyer & $13.27 \%$ & & $11.50 \%$ & \\
Professor & $12.53 \%$ & & $12.33 \%$ & \\
Audit Committee Member & $* * * 34.29 \%$ & $21.53 \%$ & $* * * 33.96 \%$ & $22.24 \%$ \\
Governance $\quad$ Committee & & & & \\
Member & $* * * 35.72 \%$ & $28.16 \%$ & $* * * 38.36 \%$ & $27.52 \%$ \\
Risk Committee Member & $* * * 14.91 \%$ & $10.18 \%$ & $* * * 29.76 \%$ & $20.11 \%$ \\
Average Membership Number & $* * 3.52$ & 3.22 & $* * 3.73$ & 3.24 \\
Independent Member & $* * * 36.23 \%$ & $23.01 \%$ & $* * * 36.23 \%$ & $24.04 \%$ \\
Busy Director & $* * 11.88 \%$ & $7.56 \%$ & $* * * 13.50 \%$ & $7.98 \%$ \\
Share Ownership \% & $* * * 1.28 \%$ & $2.71 \%$ & $* * * 1.47 \%$ & $2.56 \%$ \\
\hline
\end{tabular}

$* * *, * *$, and $*$ present significance at $1 \%, 5 \%$, and $10 \%$ levels.

In terms of director busyness, it is observed that a significantly higher percentage of financial experts, accounting experts and professors are busy directors, compared to other directors. On the other hand, Appendix 2 shows that professional experts, except financial experts, have a significantly lower percentage of share ownership in firms. The average share ownership by accounting experts is $0.38 \%$, whereas it is $0.61 \%$ and $0.05 \%$ for lawyers and professors, consecutively. If companies considered share ownership by directors as a mechanism to align the interests of directors and shareholders, one could argue that companies do not feel the need to provide such incentives to professional experts. This would be valid if they believe that those professionals would be more effective monitors, as a result of their knowledge and skills earned. Still, this could be an outcome of the fact that a high percentage of these directors are independent directors and the PCG require independent directors not to own more than $1.00 \%$ of shares in companies. For the end of 2012, we observe similar patterns.

In Table 3, I compare characteristics of various appointments of professional experts to nonexperts. However, I define a director with any one of the following expertise as a professional expert: financial expert, accounting expert, lawyer or professor. Results presented in Table 3 are supportive of the previous arguments made, based on the figures presented in Appendix 2. As observed in Table 3, at the end of 2013 a significantly lower percentage of directors with professional expertise are CEOs or chairmen of companies, compared to directors who do not have the professional expertise. 
$5.49 \%$ of professional experts are CEOs and $10.81 \%$ of them are chairmen in companies. In addition, a significantly higher percentage of them have degrees earned from institutions located outside of Turkey, $43.68 \%$, and a higher percentage of them have advanced educational degrees such as PhDs, $16.37 \%$.

In terms of committee appointments, a significantly higher percentage of professional experts are assigned to committees of the boards, compared to other directors. $33.96 \%$ of them are assigned to audit committees, whereas $38.36 \%$ of them are assigned governance

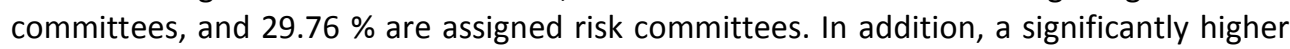
percentage of them are independent directors, compared to other directors, $36.23 \%$, whereas a significantly higher percentage of them are busy directors, $13.50 \%$. Lastly, their average share ownership is significantly lower, $1.47 \%$, compared to directors who are not professional experts. Overall, results presented in Table 3 are supportive of the previous arguments made, based on the figures presented in Appendix 2 regarding the importance of professional expertise of directors.

\section{CONCLUSIONS}

In this study I investigate the educational background and professional expertise of directors in firms quoted at National and Secondary markets of Borsa Istanbul. I put an emphasis on whether or not directors from various educational and professional backgrounds are the CEOs or chairmen of firms, as well as board committees on which they serve, and their independence, busyness, and share ownership. These topics are important in understanding whether or not companies in an economy such as the Turkish economy, where majority of public firms are controlled by families or business groups, appoint educated professionals to their boards of directors.

The main findings reveal that, compared to other directors, a higher percentage of directors with advanced degrees such as PhDs, serve on various board committees, and are assigned as independent directors to boards. A similar situation is observed for directors with at least a college degree, compared to directors who have high school degrees or lower education. However, the same cannot be stated for directors that have degrees earned from institutions located outside of Turkey, compared to other directors. The findings also reveal that a higher percentage of directors, who are accounting experts, lawyers or professors serve on various board committees, and they are assigned as independent directors. The same cannot be stated for financial expertise.

Based on these findings, one could potentially argue that advanced levels of education and professional expertise, which could lead directors to develop unique skills and technical knowledge over important corporate issues, are valued more highly by public companies. Even though a majority of companies quoted at Borsa Istanbul are controlled by families or controlling groups, they still appoint educated professionals as board committee members or independent directors, which are expected to provide effective monitoring. Directors that are assigned to committees and those who are independent hold those positions with the expectation that they could be better monitors providing superior oversight to the board of directors of companies. Based on this assumption, it is possible to argue that educated professionals are considered more effective monitors by public firms in Turkey. 
A surprising finding in the paper is that a lower percentage of directors, who have advanced educational degrees or who are professional experts, are assigned as the CEO or the chairmen of the companies. This could be an outcome of the preferences by the controlling families or groups. They could potentially be appointing educated experts to positions, where unique skills and experiences could be important in monitoring effectiveness. And they could be assigning family members or employees of controlling groups as top executives or head of boards that could require superior managerial skills, as opposed to technical skills.

The findings in the paper show that, even though there are no mandatory regulations about the technical expertise of directors and their committee appointments, as opposed to US markets, public companies in Turkey still value and appoint educated experts to important committee positions. However, it should be kept in mind that these educated professionals would not necessarily lead to increased firm performance or enhanced shareholder wealth. These professionals could potentially be more beneficial in companies dealing with more technical issues, such as technology companies, whereas similar results might not be observed in other companies. After all, as argued by Coles et al. (2008), just as one optimal board size might not fit every firm, educated professionals might not be value-creating for all types of firms.

In future studies, researchers can investigate causally how the existence of educated professional affect firm value in regression settings considering potential endogeneity problems. In addition, they could investigate the market reaction given to the appointments or departures of these directors to boards, in event study settings.

Also, they could estimate the likelihood of educated professional directors being appointed to boards of public firms, or being appointed as busy directors to other firms' boards, following certain corporate events.

\section{REFERENCES}

- $\quad$ Agrawal, A. and Chadha, S. (2005). Corporate Governance and Accounting Scandals. Journal of Law and Economics, Vol. 48, No. 2, pp.371-406.

- $\quad$ Anderson, R. C., Reeb, D. M., Upadhyay, A. and Zhao, W. (2011). The Economics of Director Heterogeneity. Financial Management, Vol. 40, No. 1, pp.5-38.

- $\quad$ Ararat, M., Orbay, H. and Yurtoglu, B. B. (2010). The Effects of Board Independence in Controlled Firms: Evidence from Turkey. Working Paper (Abstract available at http://ssrn.com/abstract=1663403).

- $\quad$ Arfken, D., Bellar, S. L. and Helms, M. M. (2004). The Ultimate Glass Ceiling Revisited: The Presence of Women on Corporate Boards. Journal of Business Ethics, Vol. 50, pp.177-186. 
- $\quad$ Arioglu, E. (2014). Demographic Diversity in the Boardroom: Evidence from Borsa Istanbul. Working Paper (Abstract available at http://ssrn.com/abstract=2473591).

- $\quad$ Arioglu, E. and Kaya, P. A. (2014). Busyness, Independence, and Advising at Borsa Istanbul Firms. Working Paper (Abstract available at http://ssrn.com/abstract=2468858).

- Audretsch, D. B. and Lehmann, E. (2006). Entrepreneurial Access and Absorption of Knowledge Spillovers: Strategic Board and Managerial Composition of Competitive Advantage. Journal of Small Business Management, Vol. 44, No. 2, pp.155-166.

- $\quad$ Bhagat, S., Bolton, B. J. and Subramanian, A. (2010). CEO Education, CEO Turnover, and Firm Performance. Working Paper (Abstract available at http://ssrn.com/abstract=1670219).

- Burgess, Z. and Tharenous, P. (2002). Women Board Directors: Characteristics of the Few. Journal of Business Ethics, Vol. 37, pp.39-49.

- Carpenter, M. A. and Westphal, J. D. (2001). The Strategic Context of External Network Ties: Examining the Impact of Director Appointments on Board Involvement in Strategic Decision Making. Academy of Management Journal, Vol. 4, No. 4, pp.639-660.

- Carter, D. A., Simkins, B. J. and Simpson, W. G. (2003). Corporate Governance, Board Diversity, and Firm Value. Financial Review, Vol. 38, No. 1, pp.33-53.

- Chan, K. C. and Li, J. (2008). Audit Committee and Firm Value: Evidence on Outside Top Executives as Expert-Independent Directors. Corporate Governance: An International Review, Vol. 16, No. 1, pp.16-31.

- Coles, J. L., Daniel, N. D. and Naveen, L. (2008). Boards: Does One Size Fit All?. Journal of Financial Economics, Vol. 87, No. 2, pp.329-356.

- Dalziel, T., Gentry, R. J. and Bowerman, M. (2011). An Integrated AgencyResource Dependence View of the Influence of Directors' Human and Relational Capital on Firms' R\&D Spending. Journal of Management Studies, Vol. 48, No. 6, pp.1217-1242. 
- Defond, M. L., Hann, R. N. and Hu, X. (2005). Does the Market Value Financial Expertise on Audit Committees of Boards of Directors. Journal of Accounting Research, Vol. 43, No. 2, pp.153-193.

- Dobbin, F. and Jung, J. (2011). Corporate Board Gender Diversity and Stock Performance: The Competence Gap or Institutional Investor Bias. North Carolina Law Review, Vol. 89, pp.809-838.

- $\quad$ Erhardt, N. L., Werbel, J. D. and Shrader, C. B. (2003). Board of Director Diversity and Firm Financial Performance. Corporate Governance: An International Review, Vol. 11, No. 2, pp.102-111.

- Ferreira, D. (2010). Board Diversity. Corporate Governance: A Synthesis of Theory, Research, and Practice, Anderson, R. and H.K. Baker (eds.), John Wiley \& Sons, 2010, pp.225-242.

- $\quad$ Fich, E. M. and Shivdasani, A. (2006). Are Busy Boards Effective Monitors?. Journal of Finance, Vol. 61, No. 2, pp.689-724.

- Forbes, D. P. and Milliken, F. J. (1999). Cognition and Corporate Governance: Understanding Boards of Directors as Strategic Decision-Making Groups. Academy of Management Review, Vol. 24, No. 3, pp.489-505.

- Francis, B., Hasan, I. and Wu, Q. (2014). Professors in the Boardroom and Their Impact on Corporate Governance and Firm Performance. Financial Management (forthcoming).

- Gottesman, A. A. and Morey, M. R. (2006). Does a Better Education Make for Better Managers? An Empirical Examination of CEO Educational Quality and Firm Performance. Working Paper (Abstract available at http://ssrn.com/abstract=564443).

- $\quad$ Gray, S. and Nowland, J. (2014). Professional Expertise and Board Diversity. Working Paper (Abstract available at http://ssrn.com/abstract=2289689).

- Guner, B. A., Malmendier, U. and Tate, G. (2008). Financial Expertise of Directors. Journal of Financial Economics, Vol. 88, No. 2, pp.323-354.

- Hermalin, B. E. and Weisbach, M. S. (1991). The Effects of Board Composition and Direct Incentives on Firm Performance. Financial Management, Vol. 20, No. 4, pp.101-112.

- Hillman, A. J., Canella, A. A. and Harris, I. C. (2002). Women and Racial Minorities in the Boardroom: How Do Directors Differ?. Journal of Management, Vol. 28, No. 6, pp.747-763. 
- Jalbert, T., Furumo, K. and Jalbert, M. (2010). Does Educational Background Affect CEO Compensation and Firm Performance?. Journal of Applied Business Research, Vol. 27, No. 1, pp.15-40.

- Jiang, B. and Murphy, P. J. (2007). Do Business School Professors Make Good Executive Managers?. Academy of Management Perspectives, Vol. 21, No. 3, pp.29-50.

- Krishnan, G. V. and Gnanakumar, V. (2008). Does the SOX Definition of an Accounting Expert Matter? The Association between Audit Committee Directors' Accounting Expertise and Accounting Conservatism. Contemporary Accounting Research, Vol. 25, No. 3, pp.827-858.

- Kroszner, R. S. and Strahan, P. E. (2001). Bankers on Boards: Monitoring, Conflicts of Interest, and Lender Liability. Journal of Financial Economics, Vol. 62, No. 3, pp.415-452.

- $\quad$ Litov, L. P., Sepe, S. M. and Whitehead, C. K. (2014). Lawyers and Fools: LawyerDirectors in Public Corporations. Cornell Law Faculty Publications, Paper 673.

- Peterson, C. A. and Philpot, J. (2007). Women's Role on US Fortune 500 Boards: Director Expertise and Committee Memberships. Journal of Business Ethics, Vol. 72, pp.177-196.

- $\quad$ Rosenstein, S. and Wyatt, J. (1990). Outside Directors, Board Independence and Shareholder Wealth. Journal of Financial Economics, Vol. 26, No. 2, pp.175-191.

- $\quad$ Ruigrok, W., Peck, S., Tacheva, S., Greve, P. and Hu, Y. (2006). The Determinants and Effects of Board Nomination Committees. Journal of Management and Governance, Vol. 10, pp.119-148.

- Shin, T. (2012). The Gender Gap in Executive Compensation: The Role of Female Directors and Chief Executive Officers. The ANNALS of the American Academy of Political and Social Science, Vol. 639, No. 1, pp.258-278.

- Sisli-Ciamarra, E. (20129. Monitoring by Affiliated Bankers on Board of Directors: Evidence from Corporate Financing Outcomes. Financial Management, Vol. 41, No. 3, pp.665-702.

- Van Ness, R. K., Miesing, P. and Kang, J. (2010). Board of Director Composition and Financial Performance in a Sarbanes-Oxley World. Academy of Business and Economics Journal, Vol. 10, No. 5, pp.56-74.

- Westphal, J. D. and Bednar, M. K. (2005). Pluralistic Ignorance in Corporate Boards and Firms' Strategic Persistence in Response to Low Firm Performance. Administrative Science Quarterly, Vol. 50, No. 2, pp.262-298. 
Appendix 1: Director Education

\begin{tabular}{|c|c|c|c|c|c|c|c|c|}
\hline & \multicolumn{8}{|c|}{ PANEL A: 2012} \\
\hline & $\begin{array}{r}\text { PhD } \\
\text { Degree }\end{array}$ & $\begin{array}{l}\text { Lower } \\
\text { Degree }\end{array}$ & $\begin{array}{c}\text { Masters } \\
\text { Degree }\end{array}$ & $\begin{array}{l}\text { Lower } \\
\text { Degree }\end{array}$ & $\begin{array}{l}\text { College } \\
\text { Degree }\end{array}$ & $\begin{array}{l}\text { Lower } \\
\text { Degree }\end{array}$ & $\begin{array}{r}\text { High School } \\
\text { or Lower }\end{array}$ & $\begin{array}{l}\text { Higher } \\
\text { Degree }\end{array}$ \\
\hline Number of Directors & 181 & 1664 & 567 & 1097 & 1006 & 91 & 91 & 1754 \\
\hline Female & $* * * 4.42 \%$ & $11.84 \%$ & $12.35 \%$ & $11.58 \%$ & $* * 11.03 \%$ & $17.58 \%$ & $* * 17.58 \%$ & $10.78 \%$ \\
\hline CEO of the Firm & $5.52 \%$ & $7.69 \%$ & $8.64 \%$ & $7.20 \%$ & $7.36 \%$ & $5.49 \%$ & $5.49 \%$ & $7.58 \%$ \\
\hline Chairman & $* * * 5.03 \%$ & $15.63 \%$ & *17.89\% & $14.47 \%$ & $* * * 13.25 \%$ & $28.09 \%$ & $* * * 28.09 \%$ & $13.90 \%$ \\
\hline Foreigner & $11.60 \%$ & $10.69 \%$ & $11.64 \%$ & $10.20 \%$ & $* * * 11.03 \%$ & $1.10 \%$ & $* * * 1.1 \%$ & $11.29 \%$ \\
\hline Foreign education & $* * * 63.54 \%$ & $39.99 \%$ & $* * * 71.2 \%$ & $23.80 \%$ & $* * * 25.77 \%$ & $2.20 \%$ & $* * * 2.2 \%$ & $44.39 \%$ \\
\hline Financial expert & $* * * 56.91 \%$ & $37.37 \%$ & $* * * 41.06 \%$ & $35.43 \%$ & $* * * 36.78 \%$ & $20.88 \%$ & $* * * 20.88 \%$ & $40.28 \%$ \\
\hline Accounting Expert & $* 7.73 \%$ & $11.73 \%$ & $* * * 7.24 \%$ & $14.10 \%$ & $* * * 15.2 \%$ & $2.20 \%$ & $* * * 2.2 \%$ & $11.82 \%$ \\
\hline Lawyer & $* * * 13.81 \%$ & $5.62 \%$ & $* 4.24 \%$ & $6.34 \%$ & $* * * 6.93 \%$ & $0.00 \%$ & $* * * 0.00 \%$ & $6.77 \%$ \\
\hline Professor & $* * * 49.17 \%$ & $1.57 \%$ & $* * * 2.65 \%$ & $1.01 \%$ & $1.10 \%$ & $0.00 \%$ & $* * * 0.00 \%$ & $6.60 \%$ \\
\hline Audit Committee Member & $* * * 52.87 \%$ & $25.31 \%$ & $23.91 \%$ & $26.05 \%$ & $* * * 27.21 \%$ & $11.69 \%$ & $* * * 11.69 \%$ & $28.77 \%$ \\
\hline Governance $\quad$ Committee & & & & & & & & \\
\hline Member & $* * * 44.25 \%$ & $30.35 \%$ & $29.01 \%$ & $31.05 \%$ & $* * * 31.88 \%$ & $20.78 \%$ & $* * 20.78 \%$ & $32.23 \%$ \\
\hline Risk Committee Member & $* * * 19.54 \%$ & $11.83 \%$ & $11.69 \%$ & $11.92 \%$ & $* * 12.36 \%$ & $6.49 \%$ & $* * 6.49 \%$ & $12.88 \%$ \\
\hline Average Membership Number & $* * * 2.47$ & 3.51 & $* * * 3.81$ & 3.34 & 3.33 & 3.54 & 3.54 & 3.39 \\
\hline Age & $* 55.77$ & 54.15 & $* * * 52.58$ & 54.95 & $* 54.77$ & 56.87 & $* * 56.87$ & 54.18 \\
\hline Independent & $* * * 54.70 \%$ & $27.01 \%$ & $25.57 \%$ & $27.76 \%$ & $* * * 29.14 \%$ & $11.62 \%$ & $* * * 11.62 \%$ & $30.62 \%$ \\
\hline Busy Director & $* * * 18.01 \%$ & $9.17 \%$ & $9.94 \%$ & $8.79 \%$ & $* * * 9.62 \%$ & $0.00 \%$ & $* * * 0 \%$ & $10.57 \%$ \\
\hline Share Ownership \% & $* * * 0.47 \%$ & $2.18 \%$ & $* * * 1.49 \%$ & $2.53 \%$ & $* * * 1.97 \%$ & $8.77 \%$ & $* * * 8.77 \%$ & $1.66 \%$ \\
\hline
\end{tabular}

$* * *, * *$, and $*$ present significance at $1 \%, 5 \%$, and $10 \%$ levels. 
Appendix 1: Director Education (Cont'd)

\begin{tabular}{|c|c|c|c|c|c|c|c|c|}
\hline & \multicolumn{8}{|c|}{ PANEL B: 2013} \\
\hline & $\begin{array}{r}\text { PhD } \\
\text { Degree }\end{array}$ & $\begin{array}{l}\text { Lower } \\
\text { Degree }\end{array}$ & $\begin{array}{r}\text { Masters } \\
\text { Degree }\end{array}$ & $\begin{array}{l}\text { Lower } \\
\text { Degree }\end{array}$ & $\begin{array}{l}\text { College } \\
\text { Degree }\end{array}$ & $\begin{array}{l}\text { Lower } \\
\text { Degree }\end{array}$ & $\begin{array}{r}\text { High } \\
\text { School or } \\
\text { Lower }\end{array}$ & $\begin{array}{l}\text { Higher } \\
\text { Degree }\end{array}$ \\
\hline Number of Directors & 186 & 1645 & 543 & 1102 & 1016 & 86 & 86 & 1745 \\
\hline Female & $* * * 3.23 \%$ & $11.43 \%$ & $11.23 \%$ & $11.52 \%$ & $* * 11.12 \%$ & $16.28 \%$ & $* * 16.28 \%$ & $10.32 \%$ \\
\hline CEO of the Firm & $4.84 \%$ & $7.72 \%$ & $* 9.58 \%$ & $6.81 \%$ & $6.99 \%$ & $4.65 \%$ & $4.65 \%$ & $7.56 \%$ \\
\hline Chairman & $* * * 5.98 \%$ & $15.20 \%$ & $* 17.76 \%$ & $13.94 \%$ & $* * * 12.52 \%$ & $30.95 \%$ & $* * * 30.95 \%$ & $13.45 \%$ \\
\hline Foreigner & $11.83 \%$ & $10.70 \%$ & $11.05 \%$ & $10.53 \%$ & $* * * 11.22 \%$ & $2.33 \%$ & $* * * 2.33 \%$ & $11.23 \%$ \\
\hline Foreign education & $* * * 60.75 \%$ & $39.05 \%$ & $* * * 70.48 \%$ & $23.52 \%$ & $* * * 25.32 \%$ & $2.32 \%$ & $* * * 2.32 \%$ & $43.19 \%$ \\
\hline Financial expert & $* * * 55.91 \%$ & $39.35 \%$ & $* * * 44.92 \%$ & $36.58 \%$ & $* * 37.52 \%$ & $25.58 \%$ & $* * * 25.58 \%$ & $41.82 \%$ \\
\hline Accounting Expert & $* * 6.99 \%$ & $12.02 \%$ & $* * * 8.12 \%$ & $13.97 \%$ & $* * * 14.97 \%$ & $2.33 \%$ & $* * * 2.33 \%$ & $11.97 \%$ \\
\hline Lawyer & $* * * 11.83 \%$ & $5.13 \%$ & $4.61 \%$ & $5.38 \%$ & $* * * 5.74 \%$ & $0.00 \%$ & $* * * 0 \%$ & $6.04 \%$ \\
\hline Professor & $* * * 50.00 \%$ & $1.34 \%$ & $* * * 2.58 \%$ & $0.73 \%$ & $0.79 \%$ & $0.00 \%$ & $* * * 0 \%$ & $6.61 \%$ \\
\hline Audit Committee Member & $* * * 50.27 \%$ & $25.67 \%$ & $* 22.82 \%$ & $27.09 \%$ & $* * * 28.15 \%$ & $14.46 \%$ & $* * * 14.46 \%$ & $28.86 \%$ \\
\hline Governance Committee & & & & & & & & \\
\hline Member & $* * * 47.03 \%$ & $31.43 \%$ & $29.87 \%$ & $32.22 \%$ & $* * * 33.30 \%$ & $19.28 \%$ & $* * * 19.28 \%$ & $33.70 \%$ \\
\hline Risk Committee Member & $* * * 37.30 \%$ & $23.68 \%$ & $22.08 \%$ & $24.49 \%$ & $* * 25.33 \%$ & $14.47 \%$ & $* * 14.47 \%$ & $25.60 \%$ \\
\hline Average Membership & & & & & & & & \\
\hline Number & $* * * 2.68$ & 3.61 & $* * * 4.17$ & 3.34 & 3.34 & 3.45 & 3.45 & 3.52 \\
\hline Age & $* * 56.61$ & 54.49 & $* * * 53.21$ & 55.12 & *54.87 & 57.97 & $* * 57.97$ & 54.55 \\
\hline Independent & $* * * 53.22 \%$ & $27.66 \%$ & $* 24.49 \%$ & $29.22 \%$ & $* * * 30.51 \%$ & $13.95 \%$ & $* * * 13.95 \%$ & $31.06 \%$ \\
\hline Busy Director & $16.76 \%$ & $10.25 \%$ & $11.22 \%$ & $9.78 \%$ & $* * * 10.64 \%$ & $0.00 \%$ & $* * * 0 \%$ & $11.47 \%$ \\
\hline Share Ownership \% & $* * * 0.46 \%$ & $2.24 \%$ & $* * * 1.41 \%$ & $2.64 \%$ & $* * * 2.13 \%$ & $8.75 \%$ & $* * * 8.75 \%$ & $1.73 \%$ \\
\hline
\end{tabular}

$* * *, * *$, and $*$ present significance at $1 \%, 5 \%$, and $10 \%$ levels. 
Appendix 2: Director Professional Expertise

\begin{tabular}{|c|c|c|c|c|c|c|c|c|}
\hline & \multicolumn{8}{|c|}{ PANEL A: 2012} \\
\hline & $\begin{array}{r}\text { Financial } \\
\text { Expert } \\
\end{array}$ & $\begin{array}{r}\text { Non- } \\
\text { Financial } \\
\text { Expert }\end{array}$ & $\begin{array}{r}\text { Accounting } \\
\text { Expert }\end{array}$ & $\begin{array}{l}\text { Non- } \\
\text { Account. } \\
\text { Expert }\end{array}$ & Lawyer & $\begin{array}{r}\text { Non- } \\
\text { Lawyer }\end{array}$ & Professor & $\begin{array}{r}\text { Non- } \\
\text { professor }\end{array}$ \\
\hline Number of Directors & 745 & 1153 & 210 & 1675 & 126 & 1844 & 119 & 1850 \\
\hline CEO of the Firm & $* * 5.64 \%$ & $8.32 \%$ & $4.76 \%$ & $7.70 \%$ & $* * 2.38 \%$ & $7.75 \%$ & $5.04 \%$ & $7.57 \%$ \\
\hline Chairman & $13.06 \%$ & $15.35 \%$ & $* * * 3.33 \%$ & $15.91 \%$ & $* * * 4.03 \%$ & $15.08 \%$ & $* * * 1.68 \%$ & $15.21 \%$ \\
\hline Foreign education & $* * * 49.23 \%$ & $37.72 \%$ & $* * * 22.22 \%$ & $44.78 \%$ & $37.29 \%$ & $42.75 \%$ & $* * * 58.36 \%$ & $41.34 \%$ \\
\hline PhD Degree & $* * * 14.36 \%$ & $7.03 \%$ & $* * 6.87 \%$ & $10.43 \%$ & $* * * 21.18 \%$ & $9.17 \%$ & $* * * 77.39 \%$ & $5.34 \%$ \\
\hline Masters Degree & $32.35 \%$ & $30.05 \%$ & $* * * 19.82 \%$ & $32.81 \%$ & $* * 20.33 \%$ & $31.88 \%$ & $* * * 13.04 \%$ & $32.03 \%$ \\
\hline College Degree & $50.62 \%$ & $56.31 \%$ & $* * * 71.73 \%$ & $52.31 \%$ & $58.48 \%$ & $54.52 \%$ & $* * * 9.56 \%$ & $57.26 \%$ \\
\hline High School or Lower & $* * 2.67 \%$ & $6.61 \%$ & $* * 1.58 \%$ & $4.45 \%$ & $* * * 0.00 \%$ & $4.43 \%$ & $* * * 0.00 \%$ & $5.34 \%$ \\
\hline Financial expert & & & $* * * 60.58 \%$ & $36.05 \%$ & $36.36 \%$ & $39.38 \%$ & $* * * 54.7 \%$ & $38.16 \%$ \\
\hline Accounting Expert & $* * * 17.31 \%$ & $7.13 \%$ & & & $* 6.67 \%$ & $11.44 \%$ & $13.04 \%$ & $11.01 \%$ \\
\hline Lawyer & $5.94 \%$ & $6.69 \%$ & $3.81 \%$ & $6.68 \%$ & & & $9.24 \%$ & $6.21 \%$ \\
\hline Professor & $* * * 8.64 \%$ & $4.60 \%$ & $7.14 \%$ & $5.97 \%$ & $8.73 \%$ & $5.86 \%$ & & \\
\hline Audit Comm. Member & $29.74 \%$ & $26.64 \%$ & $* * * 49.51 \%$ & $25.23 \%$ & $* * * 41.13 \%$ & $27.07 \%$ & $* * * 68.1 \%$ & $25.32 \%$ \\
\hline Governance $\quad$ Comm. & & & & & & & & \\
\hline Member & $32.24 \%$ & $31.72 \%$ & $* * * 48.04 \%$ & $29.82 \%$ & $* * * 43.55 \%$ & $31.29 \%$ & $* * * 49.13 \%$ & $30.93 \%$ \\
\hline Risk Comm. Member & $13.93 \%$ & $11.68 \%$ & $* * 17.65 \%$ & $12.05 \%$ & $15.32 \%$ & $12.12 \%$ & $* * 19.82 \%$ & $11.84 \%$ \\
\hline Average Membership \# & $* * * 3.77$ & 3.13 & 3.23 & 3.39 & $* * 2.64$ & 3.39 & $* * 2.28$ & 3.41 \\
\hline Independent Member & $* 32.26 \%$ & $27.77 \%$ & $* * * 49.28 \%$ & $26.99 \%$ & $* * * 44.44 \%$ & $28.45 \%$ & $* * * 70.59 \%$ & $26.78 \%$ \\
\hline Busy Director & $* * * 12.33 \%$ & $7.99 \%$ & $* * * 18.13 \%$ & $8.63 \%$ & $* 5.30 \%$ & $9.80 \%$ & $* * * 25.71 \%$ & $8.45 \%$ \\
\hline Share Ownership \% & $* 1.58 \%$ & $2.27 \%$ & $* * * 0.39 \%$ & $2.22 \%$ & $* * * 0.43 \%$ & $2.15 \%$ & $* * * 0.06 \%$ & $2.17 \%$ \\
\hline
\end{tabular}

$* * *, * *$, and $*$ present significance at $1 \%, 5 \%$, and $10 \%$ levels. 
Appendix 2: Director Professional Expertise (Cont'd)

\begin{tabular}{|c|c|c|c|c|c|c|c|c|}
\hline & \multicolumn{8}{|c|}{ PANEL B: 2013} \\
\hline & $\begin{array}{r}\text { Financial } \\
\text { Expert }\end{array}$ & $\begin{array}{r}\text { Non- } \\
\text { Financial } \\
\text { Expert }\end{array}$ & $\begin{array}{r}\text { Accounting } \\
\text { Expert }\end{array}$ & $\begin{array}{l}\text { Non- } \\
\text { Account. } \\
\text { Expert }\end{array}$ & Lawyer & $\begin{array}{r}\text { Non- } \\
\text { Lawyer }\end{array}$ & Professor & $\begin{array}{r}\text { Non- } \\
\text { Professor }\end{array}$ \\
\hline Number of Directors & 769 & 1105 & 213 & 1653 & 111 & 1825 & 119 & 1816 \\
\hline CEO of the Firm & $* * 5.72 \%$ & $8.42 \%$ & $4.69 \%$ & $7.68 \%$ & $9.91 \%$ & $11.07 \%$ & $5.04 \%$ & $7.43 \%$ \\
\hline Chairman & $12.52 \%$ & $15.21 \%$ & $* * * 4.23 \%$ & $15.45 \%$ & $* * * 3.67 \%$ & $14.79 \%$ & $* * * 2.52 \%$ & $14.94 \%$ \\
\hline Foreign education & $* * * 46.71 \%$ & $37.20 \%$ & $* * * 25.36 \%$ & $43.12 \%$ & $38.68 \%$ & $41.42 \%$ & $* * * 54.78 \%$ & $40.35 \%$ \\
\hline PhD Degree & $* * * 13.95 \%$ & $7.66 \%$ & $* * 6.70 \%$ & $10.74 \%$ & $* * * 21.05 \%$ & $9.54 \%$ & $* * * 79.51 \%$ & $5.44 \%$ \\
\hline Masters Degree & $* 32.61 \%$ & $27.85 \%$ & $* * * 21.16 \%$ & $30.93 \%$ & $* * 23.88 \%$ & $30.07 \%$ & $* * * 12.76 \%$ & $30.88 \%$ \\
\hline College Degree & $* 50.46 \%$ & $58.50 \%$ & $* * * 70.92 \%$ & $52.91 \%$ & $55.06 \%$ & $55.43 \%$ & $* * * 7.72 \%$ & $58.64 \%$ \\
\hline High School or Lower & $* 2.97 \%$ & $5.98 \%$ & $* * * 1.22 \%$ & $5.42 \%$ & $* * * 0.00 \%$ & $4.95 \%$ & $* * * 0.00 \%$ & $5.03 \%$ \\
\hline Financial expert & & & $* * * 60.66 \%$ & $38.12 \%$ & $34.91 \%$ & $41.42 \%$ & $* * * 58.11 \%$ & $39.90 \%$ \\
\hline Accounting Expert & $* * * 16.91 \%$ & $7.52 \%$ & & & $* * 5.71 \%$ & $11.75 \%$ & $11.30 \%$ & $11.42 \%$ \\
\hline Lawyer & $4.82 \%$ & $6.26 \%$ & $* 2.82 \%$ & $5.99 \%$ & & & $* 9.24 \%$ & $5.50 \%$ \\
\hline Professor & $* * * 8.85 \%$ & $4.44 \%$ & $6.10 \%$ & $6.17 \%$ & $* 9.91 \%$ & $5.92 \%$ & & \\
\hline Audit Comm. Member & $29.45 \%$ & $27.12 \%$ & $* * * 45.89 \%$ & $25.89 \%$ & $* * * 50.00 \%$ & $26.77 \%$ & $* * * 69.49 \%$ & $25.33 \%$ \\
\hline Governance $\quad$ Comm. & & & & & & & & \\
\hline Member & $34.95 \%$ & $31.69 \%$ & $* * * 51.21 \%$ & $30.76 \%$ & $* * * 44.55 \%$ & $32.31 \%$ & $* * * 53.38 \%$ & $31.62 \%$ \\
\hline Risk Comm. Member & $* 27.23 \%$ & $23.49 \%$ & $* * * 35.27 \%$ & $23.86 \%$ & $30.91 \%$ & $24.32 \%$ & $* * * 39.83 \%$ & $23.65 \%$ \\
\hline Average Membership \# & $* * * 4.06$ & 3.11 & $* 3.11$ & 3.55 & $* * * 2.54$ & 3.55 & $* 2.94$ & 3.53 \\
\hline Independent Member & $31.86 \%$ & $28.96 \%$ & $* * * 47.89 \%$ & $27.77 \%$ & $* * * 53.15 \%$ & $28.66 \%$ & $* * * 70.59 \%$ & $27.37 \%$ \\
\hline Busy Director & $* * * 14.38 \%$ & $8.32 \%$ & $* * * 19.51 \%$ & $9.66 \%$ & $10.28 \%$ & $10.66 \%$ & $* * * 25.00 \%$ & $9.64 \%$ \\
\hline Share Ownership \% & $1.78 \%$ & $2.17 \%$ & $* * * 0.38 \%$ & $2.27 \%$ & $* * 0.61 \%$ & $2.22 \%$ & $* * * 0.05 \%$ & $2.27 \%$ \\
\hline
\end{tabular}

$* * *, * *$, and $*$ present significance at $1 \%, 5 \%$, and $10 \%$ level 